\title{
THE PARAMETERS OPTIMIZATION OF LIQUEFIED GAS EXTRACTION OF THE YELLOW BEDSTRAW OVERGROUND PART BY THE RESPONSE SURFACE METHODOLOGY
}

\author{
A.V.Proskochilo, V.G.Demianenko, D.V.Demianenko \\ National University of Pharmacy \\ Key words: yellow bedstraw (Galium verum L.); extraction; difluorochloromethane; response surface \\ methodology; Box-Behnken design
}

\begin{abstract}
For the first time quantitative effects of liquefied gas extraction temperature, the correlation of the extractant volume and the raw material mass, humidity and the average size of the raw material particles have been analyzed in the lipophilic complex (LC) yield from the overground part of yellow bedstraw (Galium verum L.) using the response surface methodology (RSM). For this research, the four-factor and the three-level Box-Behnken design has been chosen; it contains four covariates, namely the extraction temperature $-X_{1}$, the ratio of the extractant volume $(\mathrm{ml})$ and the raw material mass $(g)-X_{2}$, the raw material humidity $-X_{3}$ and the average size of the raw material particles $-X_{4}$ based on the results of one-factor test. Twenty seven experimental studies have been conducted with three repeats in the centre of the design to assess the proper operational margin of the sum of squares. The experimental results obtained have been set at the polynomial equations of the second order using the multiple regression analysis, and analyzed by the corresponding statistical methods. With the help of solving the regression equation and by means of the analysis of the response surface of contour plots the optimal conditions of the LC extraction have been determined: the extraction temperature $-35^{\circ} \mathrm{C}$, the ratio of the extractant volume $(\mathrm{ml})$ and the raw material mass $(\mathrm{g})-8$, the raw material humidity $-7 \%$ and the average size of the raw material particles $-1 \mathrm{~mm}$. It has been found that the most significant factors for the process under research are the extraction temperature, the ratio of the extractant volume $(\mathrm{ml})$ and the raw material mass $(\mathrm{g})$, and the raw material humidity. Comparison of the data obtained with the data of literature sources confirms the relevance of the subcritical difluorochloromethane choice as an extractant for the LC obtaining. Summarizing all above-mentioned information it may be concluded that the use of liquefied difluorochloromethane for the LC extraction from the overground part of yellow bedstraw (Galium verum L.) is promising from the viewpoint of the modern pharmaceutical technology, and the use of the RSM as an instrument for the process optimization allows reducing the costs for carrying out the pharmaceutical development.
\end{abstract}

Currently, the increasing interest to extraction of bioactive substances (BAS) from the overground part of yellow bedstraw (Galium verum $L$.) is observed in the world $[3,7,8,10,21]$. For the extraction of complexes of the plant origin of different composition from yellow bedstraw, the supercritical $\mathrm{CO}_{2}$, US and extraction in the apparatus of a Soxhlet type $[3,10,12]$ were used. However, the basic disadvantages of the methods mentioned are complexity and the need of large amounts of the extractant, as well as the cost in time and material support of the process.

The liquefied gas extraction has a lot of advantages in comparison with the above-mentioned methods, among which there are reduced terms of the process and decrease in using solvents with a satisfactory target product yield $[1,2]$.

At the same time in many related studies the experiments were carried out empirically by means of changing some parameters of the extraction process with other parameters being steady. In the unplanned research, in addition to the considerable number of tests, spent time and costs, the regularities among operational characteristics were not established $[3,8,21]$.
The experiment planning is successfully used for determining the most influential factors in the multifactorial systems. The response surface methodology (RSM) is used for optimization of the process conditions taking into account the interaction between the factors. The RSM is a set of mathematical and statistical methods, which are useful for modeling and tasks analysis where the result depends on several variables [16]. The most wide application of the RSM can be found in the experiment planning, in such situations when the number of input variables impacts the results called responses, which are not that easy or impractical to depict with the help of the severe mathematical relation $[5,11,14$, 18-20]. The Box-Behnken design is a modified central composite design, which does not have fractional factorial points. In such designing, the combinations of variables are in the centre and the medial points of the edge plane of variables [9].

The general aim of this work was to use liquefied difluorochloromethane in the $\mathrm{LC}$ extraction from the overground part of yellow bedstraw and develop the effective extraction process. The RSM was used for the extraction conditions optimization (temperature, the ra- 
Table 1

Covariates and their elevations in the Box-Behnken design construction

\begin{tabular}{|l|c|c|c|c|}
\hline \multirow{2}{*}{ Covariates } & \multirow{2}{*}{ Symbol } & \multicolumn{4}{|c|}{ Factor level } \\
\cline { 3 - 5 } & & -1 & 0 & 1 \\
\hline Extraction temperature, ${ }^{\circ} \mathrm{C}$ & $\mathrm{X}_{1}$ & 20 & 35 & 50 \\
\hline $\begin{array}{l}\text { Ratio of the extractant } \\
\text { volume (ml) and the raw } \\
\text { material mass (g) }\end{array}$ & $\mathrm{X}_{2}$ & 2 & 8 & 14 \\
\hline Raw material humidity, \% & $\mathrm{X}_{3}$ & 4 & 7 & 10 \\
\hline $\begin{array}{l}\text { Average size of the raw } \\
\text { material particles, } \mathrm{mm}\end{array}$ & $\mathrm{X}_{4}$ & 0.25 & 1 & 1.75 \\
\hline
\end{tabular}

tio of the extractant to the raw material, humidity and the average size of the raw material particles).

\section{Experimental Part}

The object of the research was the crushed dried herb of yellow bedstraw collected during the flowering period [15].

All reagents were of analytical purity.

The experiments were carried out on the experimental plant developed by us, which provides the extraction in a closed cycle, and were successfully tested using industrial equipment.

The liquefied difluorochloromethane was used as an extractant (freon-22).

The herb of yellow bedstraw (Galium verum L.) was subjected to extraction; it was crushed to the particles size of $0.25-1.75 \mathrm{~mm}$ with humidity of $4-10 \%$, in the ratio of the raw material to the extractant of 1:2-1:14, at the temperature of $20-50^{\circ} \mathrm{C}$, for 2 hours, the first $40 \mathrm{~min}$ of which the consumption flow rate of the extractant was $100 \mathrm{ml} / \mathrm{min}$ per $1 \mathrm{~kg}$ of the raw material, and the rest of the time the consumption flow rate of the extractant was reduced twice [4].

After completion of extraction the residual solvent was distilled, the extracts obtained were removed from the collector, rinsed by dichloromethane, the washings were combined with extracts and dried to the constant weight in the vacuum-drying cabinet at the temperature of $40^{\circ} \mathrm{C}$, and then in the desiccator under phosphorous oxide (V).

The $\mathrm{LC}$ yield $\mathrm{Y}, \%$, in terms of the absolute dry starting materials was calculated according to the following formula:

$$
\mathrm{Y}, \%=\frac{\mathrm{m}_{\mathrm{e}} \cdot 100}{\mathrm{~m}_{\mathrm{H}} \cdot(100-\mathrm{W})} \cdot 100,
$$

where: $\mathrm{m}_{\mathrm{e}}-$ is the mass of the LC obtained, $\mathrm{g} ; \mathrm{m}_{\mathrm{H}}-$ is the mass of the weighed amount of the herbal raw material loaded to the extractor (s), g; $\mathrm{W}$ - is humidity of the test weighed amount of the raw material, $\%$.

To determine the optimal factors of the LC subcritical difluorochloromethane extraction from the overground part of yellow bedstraw the four-factor and three-level Box-Behnken design was used. The similar designs have high statistical characteristics of optimality and provide the same precision of a model in all directions of hy- perspace at the minimal number of tests [9]. The priory information showed that the linear models were not adequate regarding the given extraction process, therefore, a task was set to develop a model of the second order in the form of a quadratic polynomial:

$$
Y=\beta_{0}+\sum_{i=1}^{k} \beta_{i} x_{i}+\sum_{i=1}^{k} \beta_{i i} x_{i}^{2}+\sum_{i=1}^{k} \sum_{j=1}^{k} \beta_{i j} x_{i} x_{j}+\varepsilon,
$$

where: $\mathrm{Y}-$ is the objective function; $\beta_{i}, \beta_{i i}, \beta_{i j}-$ are the design coefficients of the model; $k-$ is the number of the factors; $\varepsilon-$ is uncertainty between the values observed and the predicted values, respectively.

The analysis and the graph plotting were carried out using the STATISTICA software (Version 10.0 Trial). After the dispersion analysis the suitability of the polynomial model was determined through the correlation coefficient $\mathrm{R}^{2}$. Its statistical significance was verified with the help of F-test with the probability of (P) 0.001 , 0.01 or 0.05 . Significance of the regression coefficients was also verified with the help of the F-test.

Four covariates were selected, namely, the extraction temperature $-\mathrm{X}_{1}$, the ratio of the extractant volume $(\mathrm{ml})$ and the raw material mass $(\mathrm{g})-\mathrm{X}_{2}$, the raw material humidity $-X_{3}$, and the average size of the raw material particles $-\mathrm{X}_{4}$. Covariates' encoded values are shown in Tab. 1. Twenty seven experimental studies were conducted with three repeats in the centre of the design to assess the proper operational margin of the sum of squares. We duplicated each experiment and the average value of the LC yield was taken as the response, Y. Based on the previous experimental results and values, which are available in literature, covariates and their critical experimental elevations were selected as shown in Tab. 1

\section{Results and Discussion}

The results (Tab. 2) indicate that the process parameters significantly influence on the LC yield. Response values (the extract yield Y, \%) under various experimental combinations for encoded variables are given in Table 2. The yield was from $2.16 \%$ to $3.48 \%$.

Using the multiple regression analysis of the experimental data the response and factors are related by the following second-order polynomial equation:

$$
\begin{gathered}
\mathrm{Y}, \%=1.4695+0.029233 \mathrm{X}_{1}+0.0547 \mathrm{X}_{2}+ \\
+0.17495 \mathrm{X}_{3}-0.08393 \mathrm{X}_{4}-0.00025 \mathrm{X}_{1}^{2}- \\
-0.00075 \mathrm{X}_{2}^{2}-0.0117 \mathrm{X}_{3}^{2}+0.0557 \mathrm{X}_{4}^{2}- \\
-0.0003 \mathrm{X}_{1} \mathrm{X}_{2}+0.0016 \mathrm{X}_{1} \mathrm{X}_{3}+0.0016 \mathrm{X}_{1} \mathrm{X}_{4}+ \\
+0.0007 \mathrm{X}_{2} \mathrm{X}_{3}-0.0126 \mathrm{X}_{2} \mathrm{X}_{4}+0.0172 \mathrm{X}_{3} \mathrm{X}_{4}
\end{gathered}
$$

where: $\mathrm{Y}, \%$ - is the yield of $\mathrm{LC}, \mathrm{X}_{1}, \mathrm{X}_{2}, \mathrm{X}_{3}$, and $\mathrm{X}_{4}$ are encoded values of the extraction temperature, the ratio of the extractant volume $(\mathrm{ml})$ and the raw material mass (g), the raw material humidity and the average size of the raw material particle, respectively.

Analysis of variance of quadratic regression model has shown that the value of the correlation index $\mathrm{R}^{2}$ is 0.9347 . At the same time the low value of the variability index indicates a high degree of accuracy and sufficient reliability of the experimental values. 
Table 2

The four-factor Box-Behnken design for RSM and responses observed

\begin{tabular}{|c|c|c|c|c|c|}
\hline $\begin{array}{c}\text { Experiment, } \\
\text { No. }\end{array}$ & $\mathrm{X}_{1}$ & $\mathrm{X}_{2}$ & $\mathrm{X}_{3}$ & $\mathrm{X}_{4}$ & $\begin{array}{c}\text { Yield of the } \\
\text { extract }, \%\end{array}$ \\
\hline 1 & -1 & -1 & 0 & 0 & 2.16 \\
\hline 2 & -1 & 1 & 0 & 0 & 2.52 \\
\hline 3 & 1 & -1 & 0 & 0 & 3.24 \\
\hline 4 & 1 & 1 & 0 & 0 & 3.48 \\
\hline 5 & 0 & 0 & -1 & -1 & 2.68 \\
\hline 6 & 0 & 0 & -1 & 1 & 2.88 \\
\hline 7 & 0 & 0 & 1 & -1 & 2.99 \\
\hline 8 & 0 & 0 & 1 & 1 & 3.35 \\
\hline 9 & -1 & 0 & 0 & -1 & 2.83 \\
\hline 10 & -1 & 0 & 0 & 1 & 2.78 \\
\hline 11 & 1 & 0 & 0 & -1 & 3.45 \\
\hline 12 & 1 & 0 & 0 & 1 & 3.47 \\
\hline 13 & 0 & -1 & -1 & 0 & 2.47 \\
\hline 14 & 0 & -1 & 1 & 0 & 2.88 \\
\hline 15 & 0 & 1 & -1 & 0 & 2.78 \\
\hline 16 & 0 & 1 & 1 & 0 & 3.24 \\
\hline 17 & -1 & 0 & -1 & 0 & 2.73 \\
\hline 18 & -1 & 0 & 1 & 0 & 2.63 \\
\hline 19 & 1 & 0 & -1 & 0 & 3.30 \\
\hline 20 & 1 & 0 & 1 & 0 & 3.48 \\
\hline 21 & 0 & -1 & 0 & -1 & 2.99 \\
\hline 22 & 0 & -1 & 0 & 1 & 3.19 \\
\hline 23 & 0 & 1 & 0 & -1 & 3.35 \\
\hline 24 & 0 & 1 & 0 & 1 & 3.33 \\
\hline 25 & 0 & 0 & 0 & 0 & 3.45 \\
\hline 26 & 0 & 0 & 0 & 0 & 3.45 \\
\hline 27 & 0 & 0 & 0 & 0 & 3.44 \\
\hline & & & & & \\
\hline
\end{tabular}
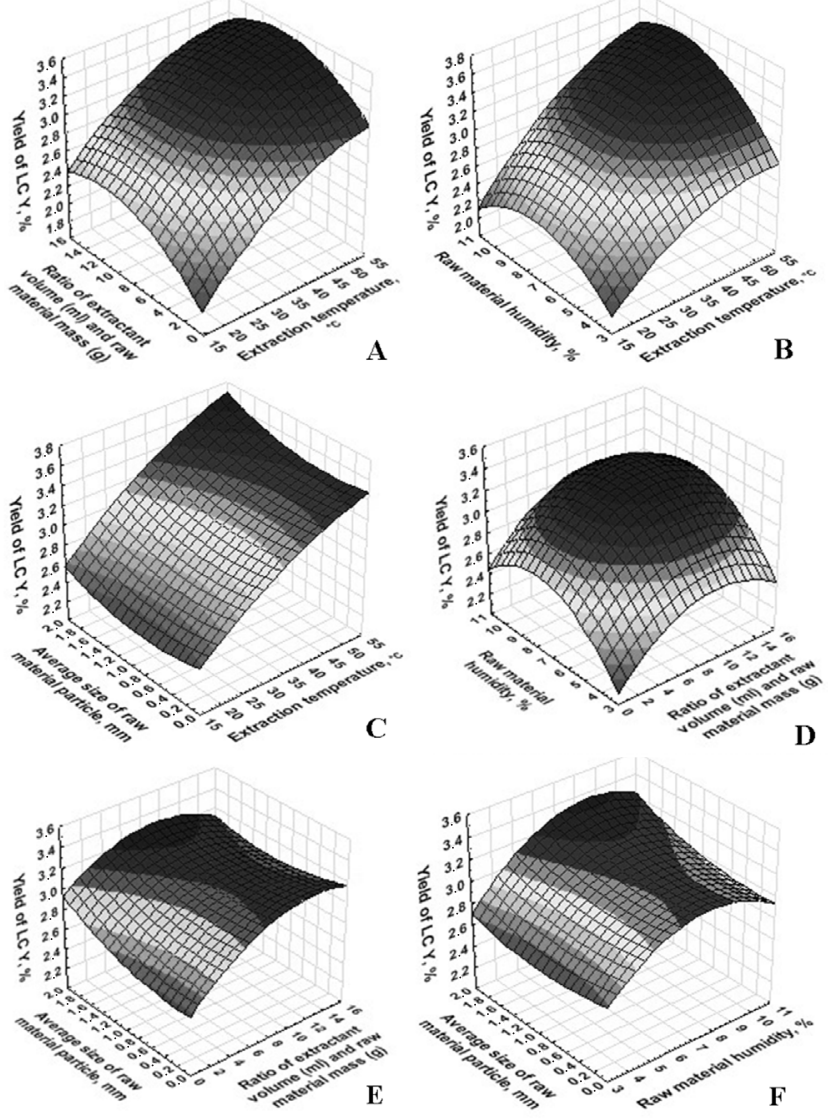

Fig. 1. Response surface plots showing the effect of variables (A) $\mathrm{X}_{1}$ and $\mathrm{X}_{2}$; (B) $\mathrm{X}_{1}$ and $\mathrm{X}_{3} ;(\mathrm{C}) \mathrm{X}_{1}$ and $\mathrm{X}_{4}$; (D) $\mathrm{X}_{2}$ and $\mathrm{X}_{3}$; (E) $X_{2}$ and $X_{4} ;(F) X_{3}$ and $X_{4}$ on the LC yield.

decreasing the size of particles $\mathrm{X}_{4}$ to the lower threshold level (Fig. 1C and 2C). Meanwhile, increase in the extraction temperature $\left(\mathrm{X}_{1}\right)$ to the central level resulted in increase in the $\mathrm{LC}$ yield as shown in Fig. 1A, $1 \mathrm{~B}$ and $1 \mathrm{C}$ and $2 \mathrm{~A}, 2 \mathrm{~B}$ and $2 \mathrm{C}$. At temperatures above this level the LC yield slightly grows due to the complete depletion of the raw material. At a temperature of the lower level the LC yield is low enough; it may be associated with unsatisfactory extractant characteristics for the process studied. It has been noticed that the temperature regime in the central level can be considered as quite thrifty. Taking into account the results obtained the heating of the extractant is impractical because of increase of energy requirement and the raw material overheating, which can cause destruction of thermolabile BAS.

Insignificant increase in the LC yield occurs even when the ratio of the extractant volume $(\mathrm{ml})$ and the raw material mass $\left(\mathrm{X}_{2}\right)$ was increased in the range from 8 to 14 (Fig. $1 \mathrm{~A}$ and $1 \mathrm{D}$ and $2 \mathrm{~A}$ and $2 \mathrm{D}$ ). When reducing the ratio of the extractant volume $(\mathrm{ml})$ and the raw material mass the LC yield is reduced, and it indicates the necessity of using additional portions of the extractant, which is energy disadvantageous considering the mode of plant operation for extraction of liquefied gases.

Fig. $1 \mathrm{~B}, 1 \mathrm{D}$ and $1 \mathrm{~F}$ and $2 \mathrm{~B}, 2 \mathrm{D}$ and $2 \mathrm{~F}$ also show that the LC yield increases with validity of the raw material humidity in the core range. It has been found experimentally that when increasing the moisture content the LC yield significantly reduces; it can be explained 

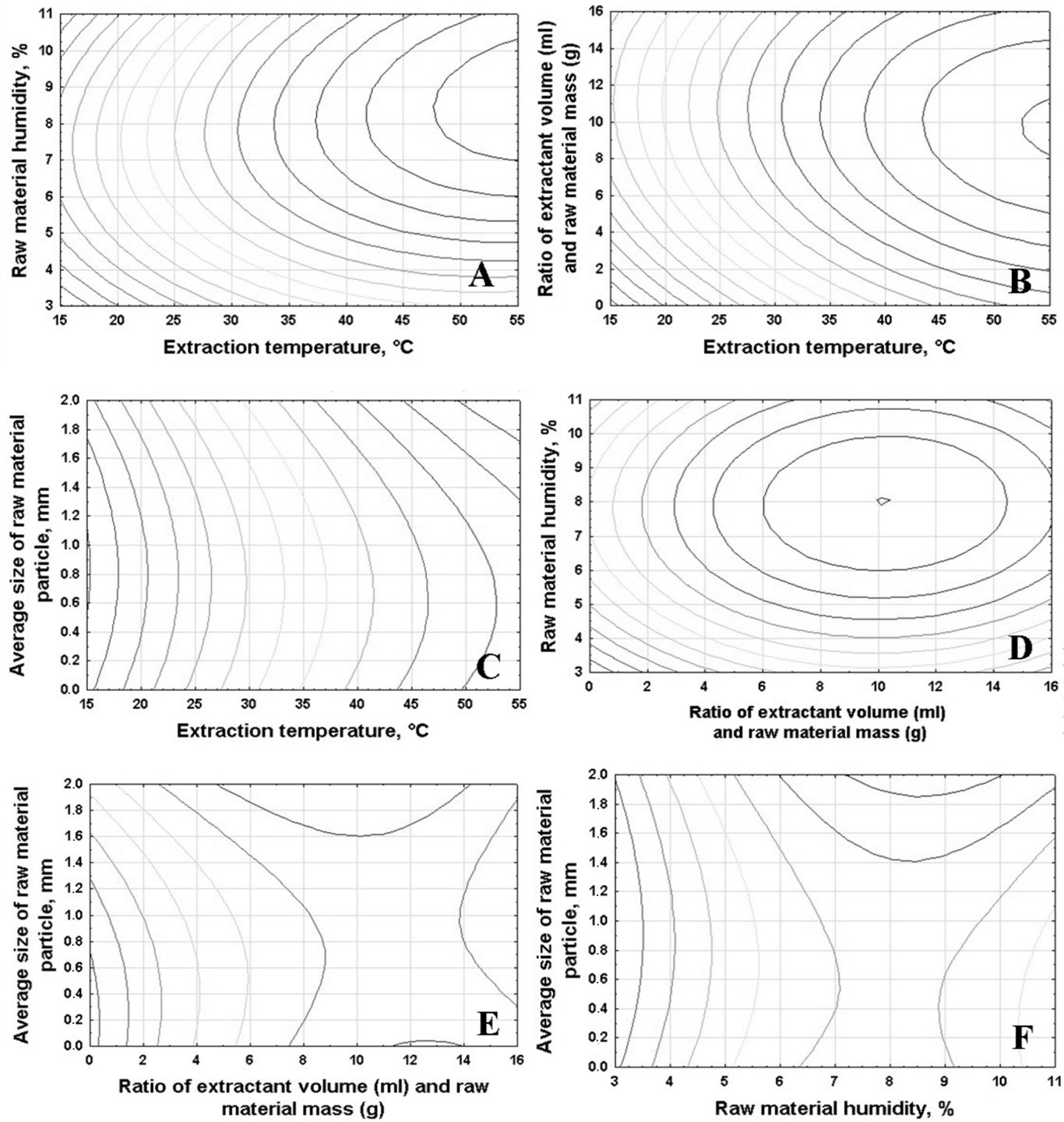

Fig. 2. Contour plots showing the effect of variables $(A) X_{1}$ and $X_{2} ;(B) X_{1}$ and $X_{3}$; (C) $X_{1}$ and $X_{4} ;(D) X_{2}$ and $X_{3} ;(E) X_{2}$ and $X_{4} ;(F) X_{3}$ and $X_{4}$ on the $L C$ yield.

by the limited difluorochloromethane absorbency. At the same time the lack of the raw material humidity also affect on the LC yield. Such dependence was observed by researchers [2, 13, 17].

Therefore, based on the abovementioned information it can be asserted that an optimal process is extraction of yellow bedstraw (Galium verum L.) herb crushed into the particles size of $1 \mathrm{~mm}$ with $7 \%$ humidity in the following ratio of the extraction raw material: the extractant of $1: 8$, at the temperature of $35^{\circ} \mathrm{C}$ for 2 hours, the first 40 minutes the extractant specific consumption should be $100 \mathrm{ml} / \mathrm{min}$ per $1 \mathrm{~kg}$ of the raw material, and the rest of the time the extractant specific consumption was reduced twice.

\section{CONCLUSIONS}

For the first time the effective process for the LC subcritical difluorochloromethane extraction from the overground part of yellow bedstraw (Galium verum L.) has been developed. The four-factor, three-level BoxBehnken design and the RSM have been applied to optimize the extraction parameters. The maximum LC yield$3.45 \%$ can be reached under the optimal conditions found and experimentally confirmed. The process developed has been tested in industrial conditions.

\section{REFERENCES}

1. Гарна С.В., Вєтров П.П. // Запорож. мед. журн. - 2010. - №3. - С. 92-94.

2. Зилфикаров И.Н. Обработка лекарственного растительного сырья сжиженными газами и сверхкритическими флюидами. - Пятигорск, 2007. - 136 с.

3. ІльӥнаТ.В. // УБФЖ. - 2009. - №5. - С. 31-36.

4. Пат. 105231 Украӥна МПК (2006) А 61 K 36/74, А 61 K 35/00. - Опубл.: 25.04.14. - Бюл. 8.

5. Annadurai G. // J. Hazard. Mater. - 2008. - Vol. 151. - P. 171-178. 
6. Bae S. Shoda M. // Biotechnol. Bioeng. - 2005. - Vol. 90, №1. - P. 20-28.

7. Chun-Chao Z., Jian-Hua S., Xian L. et al. // Nat. Prod. Res. - 2006. - Vol. 20, №11. - P. 981-984.

8. Demirezer L.Ö., Gürbüz F. // Turk. J. Chem. - 2006. - Vol. 30. - P. 525-534.

9. Ferreira S.L.C., Bruns R.E. // Anal. Chim. Acta. - 2007. - Vol. 597. - P. 179-186.

10. Li Q.J., Nan M.L. // J. Med. Plant. - 2010. - Vol. 1, №10. - P. 5-6, 9.

11. Lu J., Zhou C. // Adv. J. of Food Sci. Technol. - 2013. - Vol. 5(3). - P. 310-317.

12. Milić P.S. // CI\&CEQ. - 2013. - Vol. 19(1). - P. 141-152.

13. Milić P.S., Rajkovic K.M. // Ultrason. Sonochem. - 2013. - Vol. 20. - P. 525-534.

14. Moghaddam M.G., Khajeh M. // Food and Nutrition Sci. - 2011. - Vol. 2. - P. 803-808.

15. Proskochilo A.V., Demianenko V.G. // J. Chem. Pharm. Res. - 2014. - Vol. 6 (2). - P. 765-771.

16. Shaibu A.B., Cho B.R. // Int. J. Adv. Manuf. Technol. - 2009. - Vol. 41. - P. 631-641.

17. Wang J., Zhang J. // Carbohydr. Polym. - 2010. - Vol. 80. - P. 84-93.

18. Xu L., Liu J. // Sep. Sci. Technol. - 2013. - Vol. 48. - P. 2779-2785.

19. Yang L., Jiang J.G. // J. Sep. Sci. - 2009. - Vol. 32. - P. 1437-1444.

20. Yin G., Dang Y. // Carbohydr. Polym. - 2008. - Vol. 74. - P. 603-610.

21. Zhao C., Shao J. // China J. of Chinese Materia Medica. - 2009. - Vol. 34, №21. - P. 2761-2763.

ОПТИМІЗАЦІЯ ПАРАМЕТРІВ ЗРІДЖЕНОГАЗОВОЇ ЕКСТРАКЦІЇ НАДЗЕМНОЇ ЧАСТИНИ ПІДМАРЕННИКА СПРАВЖНЬОГО МЕТОДОЛОГІЄЮ ПОВЕРХНІ ВІДГУКУ

\section{А.В.Проскочило, В.Г.Дем'яненко, Д.В.Дем'яненко}

Ключові слова: підмаренник справжній (Galium verum L.); екстракція; дифоторохлорометан; методологія поверхні відгуку; план Бокса-Бенкена

Вперше були досліджені кількісні ефректи температури зрідженогазової екстракції, співвідношення об'єму екстрагенту та маси сировини, вологості та середнього розміру частинок сировини на вихід ліпофрільного комплексу (ЛК) із надземної частини підмаренника справжнього (Galium verum L.) із використанням методології поверхні відгуку (MПВ). Для цього дослідження було обрано чотирифракторний, трирівневий план Бокса-Бенкена, в якому чотири незалежні змінні, а саме температура екстракції - $X_{1}$, співвідношення об'єму екстрагенту (мл) і маси сировини (2) $-X_{2}$, вологість сировини $-X_{3}$ та середній розмір частинок сировини - $X_{4}$ засновані на результатах однофракторного тесту. Було проведено 27 експериментальних досліджень із трьома повторами у центрі плану, щоб оцінити чисту похибку суми квадратів. Отримані експериментальні дані були встановлені на поліноміальних рівняннях другого порядку з використанням множинного регресійного аналізу, а також проаналізовані відповідними статистичними методами. Вирішуючи рівняння регресії, а також шляхом аналізу поверхні відгуку контурних графіків були визначені оптимальні умови екстракції ЛК: температура екстракції $-35^{\circ} \mathrm{C}$, співвідношення об'єму екстрагенту (мл) і маси сировини (2) - 8, вологість сировини - 7\% та середній розмір частинок сировини - 1 мм. Було визначено, що найбільш значущими фракторами для досліджуваного процесу є температура екстракції, співвідношення об'єму екстрагенту (мл) і маси сировини (2) та вологість сировини. Порівняння отриманих даних із даними літературних джерел підтверджує актуальність вибору докритичного дифоторохлорометану в якості екстрагенту для одержання ЛК. Підсумовуючи вищевикладене, можна зробити висновок, що застосування зрідженого дифрторохлорометану для екстракції ЛК із надземної частини підмаренника справжнього (Galium verum L.) є перспективним із позицій сучасної фрармацевтичної технології, а використання МПВ у якості інструменту для оптимізації процесу дозволяє скоротити затрати на проведення фармацевтичної розробки.

\section{ОПТИМИЗАЦИЯ ПАРАМЕТРОВ СЖИЖЕННОГАЗОВОЙ ЭКСТРАКЦИИ НАДЗЕМНОЙ ЧАСТИ} ПОДМАРЕННИКА НАСТОЯЩЕГО МЕТОДОЛОГИЕЙ ПОВЕРХНОСТИ ОТКЛИКА

\section{А.В.Проскочило, В.Г.Демьяненко, Д.В.Демьяненко}

Ключевые слова: подмаренник настоящий (Galium verum L.); экстракция;

дифрторхлорметан; методология поверхности отклика; план Бокса-Бенкена

Впервые были исследованы количественные эфффекты температуры сжиженногазовой экстракции, соотношения объема экстрагента и массы сырья, влажности и среднего размера частиц сырья на выход липофильного комплекса (ЛК) из надземной части подмаренника настоящего (Galium verum L.) с использованием методологии поверхности отклика (MПО). Для этого исследования было выбрано четырехфакторный, трехуровневый план Бокса-Бенкена, в котором четыре независимые переменные, а именно температура экстракции - $X_{1}$, соотношение объема экстрагента (мл) и массы сырья (2) $-X_{2}$, влажность сырья - $X_{3}$ и средний размер частиц сырья - $X_{4}$ основаны на результатах однофракторного теста. Было проведено 27 экспериментальных исследований с тремя повторами в центре плана с целью 
оценки чистой погрешности суммы квадратов. Полученные экспериментальные данные были установлены на полиномиальных уравнениях второго порядка с использованием множественного регрессионного анализа, а также проанализированы статистическими методами. Решением уравнения регрессии, а также путем анализа поверхностей отклика контурных графиков были определены оптимальные условия экстракции ЛК: температура экстракции $35^{\circ} \mathrm{C}$, соотношение объема экстрагента (мл) и массы сырья (2) - 8, влажность сырья - 7\% и средний размер частии сырья - 1 мм. Было определено, что наиболее значимыми фракторами для исследуемого процесса является температура экстракции, соотношение объема экстрагента (мл) и массы сырья (2) и влажность сырья. Сравнение полученных данных с данными литературных источников подтверждает актуальность выбора докритического дифрторхлорметана в качестве экстрагента для получения ЛК. Подытоживая вышеизложенное, можно сделать вывод, что применение сжиженного дифторхлорметана для экстракции ЛК из надземной части подмаренника настоящего (Galium verum L.) является перспективным с позиций современной фрармацевтической технологии, а использование МПВ в качестве инструмента для оптимизации процесса позволяет сократить затраты на проведение фрармацевтической разработки. 